\title{
Enhancement of nutritional and bioactive compounds by in vitro culture of wild Fragaria vesca L. vegetative parts
}

\author{
Maria Inês Dias ${ }^{\mathrm{a}, \mathrm{b}, \mathrm{c}}$, Lillian Barros ${ }^{\mathrm{a}, \mathrm{c}}$, Maria João Sousa ${ }^{\mathrm{a}}$, M. Beatriz P.P. Oliveira ${ }^{\mathrm{b}}$, Celestino Santos-Buelga ${ }^{\mathrm{d}}$, \\ Isabel C.F.R. Ferreira ${ }^{a, *}$ \\ ${ }^{a}$ Mountain Research Centre (CIMO), ESA, Polytechnic Institute of Bragança, Campus de Santa Apolónia, 1172, 5300-253 Bragança, Portugal \\ ${ }^{\mathrm{b}}$ REQUIMTE/LAQV, Science Chemical Department, Faculty of Pharmacy of University of Porto, Rua Jorge Viterbo Ferreira, 228, 4050-313 Porto, Portugal

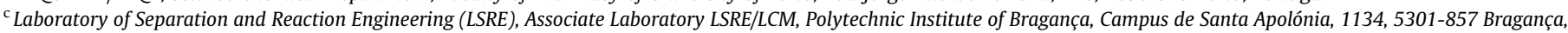 \\ Portugal \\ ${ }^{\mathrm{d}}$ Grupo de Investigación en Polifenoles (GIP-USAL), Facultad de Farmacia, Universidad de Salamanca, Campus Miguel de Unamuno s/n, 37007 Salamanca, Spain
}

\section{A R T I C L E I N F O}

\section{Article history:}

Received 19 January 2017

Received in revised form 3 May 2017

Accepted 11 May 2017

Available online 12 May 2017

\section{Keywords:}

Fragaria vesca L.

In vitro culture

Nutritional value

Phenolic compounds

\begin{abstract}
A B S T R A C T
In vitro culture emerges as a sustainable way to produce bioactives for further applicability in the food industry. Herein, vegetative parts of Fragaria vesca L. (wild strawberry) obtained by in vitro culture were analyzed regarding nutritional and phytochemical compounds, as well as antioxidant activity. These samples proved to have higher content of protein, polyunsaturated fatty acids, soluble sugars, organic acids (including ascorbic acid) and tocopherols (mainly $\alpha$-tocopherol) than wild grown $F$. vesca, as well as containing additional phenolic compounds. The antioxidant activity of hydromethanolic extracts could be correlated with the content of different phenolic groups and other compounds (sugars and organic acids). It was demonstrated that in vitro culture could enhance nutritional and bioactive compounds of Fragaria vesca L. plants, providing a very interesting biotechnological tool for potential food applications. (c) 2017 Elsevier Ltd. All rights reserved.
\end{abstract}

\section{Introduction}

Wild strawberry (Fragaria vesca L., Rosaceae family) can be commonly found in Europe, Japan, North America and Canada, growing wild in mountain zones, forests, on slopes and roadsides (Castroviejo et al., 1998). The plant is mainly appreciated for its sweet small fruits; however the vegetative parts have been described as important sources of macro and micronutrients and also phenolic compounds (procyanidins, ellagic acid and hydroxycinnamoyl derivatives) with strong antioxidant activity (Dias, Barros, Fernandes, et al., 2015; Dias, Barros, Morales, et al., 2015). Vegetative parts from $F$. vesca could provide tonic, antiseptic and detoxifying properties. Furthermore, its decoctions and infusions have been traditionally used to treat urinary tract infections and hypertension, presenting also antidiarrheal and anticoagulant activity (Camejo-Rodrigues, Ascensão, Bonet, \& Vallès, 2003; Pawlaczyk, Czerchawski, Pilecki, Lamer-Zarawska, \& Gancarz, 2009; Savo, Giulia, Maria, \& David, 2011; Özüdoru, Akaydin, Erik, \& Yesilada, 2011).

\footnotetext{
* Corresponding author.

E-mail address: iferreira@ipb.pt (I.C.F.R. Ferreira).
}

The growing demand for natural products that complement their nutritional role with additional functional properties requires innovation in the ways to obtain these products, in order to protect wild populations from where they are obtained, and also to avoid competing directly with crops that are used for food (Godfray et al., 2012). Plant tissue culture appears as a valuable technique to produce secondary metabolites, being an ecological and sustainable alternative for the production of endangered species (by overexploitation), as well as a means to obtain bioactive extracts and compounds that can be further applied in pharmaceutical/medical fields or in the food industry. Indeed, this approach has been endorsed by FAO as a safe process to produce compounds for food applications (Dias, Sousa, Alves, \& Ferreira, 2016). Regardless of climate or geographical conditions, this technique allows a continuous production of natural compounds under a very restricted controlled regime (Anand, 2010; Karuppusamy, 2009).

The nutritional value and chemical profile of vegetative parts of F. vesca were previously reported by our research group (Dias, Barros, Morales, et al., 2015). The presence of sugars and organic acids was also described in its fruits (Doumett et al., 2011; Ornelas-Paz et al., 2013), while phenolic compounds and related bioactive properties were reported in different plant parts (fruits, leaves and roots) (Dias et al., 2016; Dias, Barros, Fernandes, et al., 2015; Dias, Barros, Oliveira, Santos-Buelga, \& Ferreira, 2015c). 
These compounds were also described in $F$. vesca obtained from in vitro culture, after optimization of growth conditions (concentration of plant regulators and regeneration enhancers) (Yildirim \& Turker, 2014). Nevertheless and to the author's best knowledge, no other components have been studied.

In the present work, vegetative parts of Fragaria vesca L. were obtained by in vitro culture and further characterized in terms of macronutrients, fatty acids, soluble sugars, organic acids, tocopherols and phenolic compounds; their antioxidant activities were also studied. The studies were carried out with lyophilized material, hydromethanolic extracts and aqueous consumption forms (infusions and decoctions).

\section{Materials and methods}

\subsection{Standards and reagents}

Acetonitrile (99.9\%), $n$-hexane (95\%) and ethyl acetate (99.8\%) were of HPLC grade from Fisher Scientific (Lisbon, Portugal). Acetonitrile (fluorescence grade) was bought from Fisher Scientific (Madrid, Spain). Formic acid was purchased from Prolabo (VWR International, France). Fatty acids methyl ester (FAME) reference standard mixture (standard 47885-U) was purchased from Sigma (St. Louis, MO), alongside other individual fatty acid methyl ester isomers, Trolox (6-hydroxy-2,5,7,8-tetramethylchroman-2-car boxylic acid), 1-ascorbic acid, tocopherol, sugar and organic acid standards. Phenolic standards were from Extrasynthèse (Genay, France). 2,2-Diphenyl-1-picrylhydrazyl (DPPH) was obtained from Alfa Aesar (Ward Hill, MA,). All other general laboratory reagents were purchased from Panreac Química S.L.U. (Barcelona, Spain). Water was treated in a Milli-Q water purification system (TGI Pure Water Systems, USA).

\subsection{Samples and establishment of an in vitro culture of Fragaria vesca $L$}

The samples of wild Fragaria vesca L. fruits were collected in Serra da Nogueira, Bragança, north-eastern Portugal, in July 2013. The establishment of the in vitro culture was achieved by using the wild fruits with seeds. The fruits were washed with tap water and sterilized with bleach and detergent for 5 min under agitation, washed with sterilized water and inoculated in a basic medium for seed germination with water and agar $(0.9 \%)$ and kept in the dark until germination. The seedlings were then detached from the fruit and placed in a modified culture medium (Murashige \& Skoog, 1962) supplied with macronutrients, $1 \mathrm{mg} / \mathrm{L}$ thiamine, $1 \mathrm{mg} / \mathrm{L}$ nicotinic acid, $1 \mathrm{mg} / \mathrm{L}$ pyridoxine, $2 \%$ sucrose, $0.5 \mathrm{mg} / \mathrm{L}$ BAP (benzylaminopurine) and $0.5 \mathrm{mg} / \mathrm{L}$ IBA (indole-3-butyric acid). The $\mathrm{pH}$ culture medium was adjusted to 5.7 before autoclaving. The culture conditions were $\mathrm{Tmin}[16-18]^{\circ} \mathrm{C}$, Tmax $[24-26]^{\circ} \mathrm{C}$ with a photoperiod of $16 / 8 \mathrm{~h}$ (light/dark) supplied by light bulbs (Silvana day light; Philips, Eindhoven, Netherlands). The plants were kept under the same culture conditions and subcultured every month, collecting the aerial parts obtained under in vitro conditions and keeping the roots and shoots for further growth and collection of new material. The collected aerial parts were stored at $-20^{\circ} \mathrm{C}$, lyophilized and reduced to a fine powder for further analysis.

\subsection{Preparation of the aqueous consumption forms}

For infusions preparation, the lyophilized plant material (500 mg) was added to $100 \mathrm{~mL}$ of boiling distilled water (pH 6.6) at $100{ }^{\circ} \mathrm{C}$, left to stand at room temperature for $5 \mathrm{~min}$ and then filtered $(0.22 \mu \mathrm{m})$ under reduced pressure.
For decoctions preparation, the lyophilized plant material (500 mg) was added to $100 \mathrm{~mL}$ of distilled water, heated and boiled for $5 \mathrm{~min}$. The mixture was left to stand for $5 \mathrm{~min}$ and then filtered under reduced pressure. The extracts obtained by infusion and decoction were lyophilized for further analysis of phenolic compounds and antioxidant activity.

\subsection{Nutritional value of the lyophilized plant material}

\subsubsection{Proximate composition}

The lyophilized plant material was analyzed for proteins, fat, carbohydrates and ash according to AOAC procedures (AOAC, $2005)$. The crude protein content $(N \times 6.25)$ was estimated by the macro-Kjeldahl method (AOAC, 991.02); the crude fat (AOAC, 989.05) was determined by extracting a known weight of powdered sample with petroleum ether, using a Soxhlet apparatus; the ash content (AOAC, 935.42) was determined by incineration at $550 \pm 15^{\circ} \mathrm{C}$; Total carbohydrates were calculated by difference. Total energy was calculated according to the following equation:

Energy $(\mathrm{kcal} / 100 \mathrm{~g})=4 \times($ gproteins + gcarbohydrates $)+9 \times(\mathrm{gfat})$, according to the (Regulation (EC) No 1169/2011, 2011).

\subsubsection{Fatty acids}

Fatty acids were determined in the lyophilized plant material, after a transesterification process, as previously described (Barros et al., 2013). The fatty acids profile was analyzed using a gas chromatograph (model GC 1000 instrument; DANI, Contone, Switzerland) equipped with a split/splitless injector and a flame ionization detector (GC-FID, $260^{\circ} \mathrm{C}$ ) and a Macherey-Nagel (Düren, Germany) column ( $0.5 \mathrm{~g} / \mathrm{kg}$ cyanopropyl-methyl-0.5 g/kg phenylmethylpolysiloxane, $30 \mathrm{~m} \times 0.32 \mathrm{~mm}$ i.d. $\times 0.25 \mu \mathrm{m}$ film thickness). The oven temperature program was as follows: the initial temperature of the column was $50^{\circ} \mathrm{C}$, held for $2 \mathrm{~min}$, then a $30^{\circ} \mathrm{C} / \mathrm{min}$ ramp to $125^{\circ} \mathrm{C}, 5^{\circ} \mathrm{C} / \mathrm{min}$ ramp to $160^{\circ} \mathrm{C}, 20^{\circ} \mathrm{C} / \mathrm{min}$ ramp to $180^{\circ} \mathrm{C}, 3^{\circ} \mathrm{C} / \mathrm{min}$ ramp to $200^{\circ} \mathrm{C}, 20^{\circ} \mathrm{C} / \mathrm{min}$ ramp to $220^{\circ} \mathrm{C}$ and held for $15 \mathrm{~min}$. The carrier gas (hydrogen) flow rate was $4.0 \mathrm{~mL} / \mathrm{min}(61000 \mathrm{~Pa})$, measured at $50^{\circ} \mathrm{C}$. Split injection (1:40) was carried out at $250{ }^{\circ} \mathrm{C}$. Identifications were made by comparing the relative retention times of FAME (fatty acid methyl esters) peaks of the samples with commercial standards. The results were recorded and processed using Clarity 4.0.1.7 Software (DataApex, Prague, Czech Republic) and expressed as a relative percentage of each fatty acid.

\subsection{Chemical characterization of the lyophilized plant material and aqueous consumption forms}

\subsubsection{Soluble sugars}

The extraction of soluble sugars from the lyophilized plant material was carried out following the procedure described by Barros et al. (2013), while for the aqueous preparations the analysis was carried out directly. Soluble sugars were determined by high-performance liquid chromatography equipment consisting of an integrated system with a pump (Smartline system 1000; Knauer, Berlin, Germany), degasser system (Smartline Mmanager 5000) and autosampler (AS-2057; Jasco, Easton, MD), coupled to a refractive index detector (HPLC-RI; Smartline system 1000; Knauer, Berlin, Germany), as previously described (Barros et al., 2013). The chromatographic separation was achieved with a Eurospher $100-5 \mathrm{NH}_{2}$ column ( $5 \mu \mathrm{m}, 250 \times 4.6 \mathrm{~mm}$ i.d., Knauer) operating at $35^{\circ} \mathrm{C}$. The mobile phase was acetonitrile:deionized water $(7: 3, v / v)$, at a flow rate of $1 \mathrm{~mL} / \mathrm{min}$. The identification was carried out by chromatographic comparisons of the relative retention times of sample peaks with authentic standards, while the quan- 
tification was performed using the internal standard (melezitose) method and by using calibration curves obtained from commercial standards of each compound. The results were expressed in $\mathrm{g}$ per $100 \mathrm{~g}$ dry weight or in $\mathrm{mg}$ per $100 \mathrm{~mL}$ in the case of infusions and decoctions.

\subsubsection{Organic acids}

The extraction of organic acids from the lyophilized plant material was carried out following the procedure described by Barros et al. (2013), while for the aqueous preparations the analysis was carried out directly. Vitamin $\mathrm{C}$ and other organic acids were determined by ultra-fast liquid chromatography coupled to photodiode array detection (UFLC-PDA; Shimadzu Corporation, Kyoto, Japan) and following a procedure previously described (Barros et al., 2013). Separation was achieved on a SphereClone (Phenomenex, Torrance, CA) reverse phase $C_{18}$ column $(5 \mu \mathrm{m}, 250 \times 4.6 \mathrm{~mm})$ thermostatted at $35^{\circ} \mathrm{C}$. The elution was performed with sulfuric acid $(3.6 \mathrm{mmol} / \mathrm{L})$ using a flow rate of $0.8 \mathrm{~mL} / \mathrm{min}$. The quantification was performed by comparison of the area of the peaks recorded at $215 \mathrm{~nm}$ and $245 \mathrm{~nm}$ (for ascorbic acid) as preferred wavelengths with calibration curves obtained from commercial standards of each compound. The results were expressed in $g$ per $100 \mathrm{~g}$ of dry weight or in $\mathrm{mg}$ per $100 \mathrm{~mL}$ in the case of infusions and decoctions.

\subsubsection{Tocopherols}

The extraction of tocopherols from the lyophilized plant material was carried out following the procedure described by Barros et al. (2013), while for the aqueous preparations the analysis was carried out directly using HPLC coupled to a fluorescence detector (FP-2020; Jasco, Easton, MD) programmed for excitation at $290 \mathrm{~nm}$ and emission at $330 \mathrm{~nm}$. The chromatographic separation was achieved with a Polyamide II normal-phase column $(5 \mu \mathrm{m}$, $250 \times 4.6 \mathrm{~mm}$ i.d.; YMC, Waters Corporation, Milford, MA), operating at $35^{\circ} \mathrm{C}$. The mobile phase used was a mixture of $n$-hexane and ethyl acetate $(70: 30, v / v)$ at a flow rate of $1 \mathrm{~mL} / \mathrm{min}$. The identification was performed by chromatographic comparisons with authentic standards, while the quantification was based on the fluorescence signal response of each standard, using the internal standard (tocol) method and by using calibration curves obtained from commercial standards of each compound. The results were expressed in $\mu \mathrm{g}$ per $100 \mathrm{~g}$ of dry weight or in $\mu \mathrm{g}$ per $100 \mathrm{~mL}$ in the case of infusions and decoctions.

\subsection{Analysis of phenolic compounds and antioxidant activity of hydromethanolic extracts and aqueous consumption forms}

\subsubsection{Preparation of the hydromethanolic extracts}

The lyophilized plant material ( $1 \mathrm{~g})$ was submitted to an extraction with a methanol:water mixture $(80: 20, v / v ; 30 \mathrm{~mL})$ at $25^{\circ} \mathrm{C}$ and $150 \mathrm{rpm}$ for $1 \mathrm{~h}$, followed by filtration through a Whatman No. 4 filter paper. The residue was then extracted with one additional $30-\mathrm{mL}$ portion of the hydromethanolic mixture. The combined extracts were evaporated under reduced pressure (R-210 rotary evaporator; Büchi, Flawil, Switzerland) and further lyophilized.

\subsubsection{Phenolic compounds}

The lyophilized extracts, infusions and decoctions were redissolved in methanol:water $(80: 20, v / v)$ and pure water, respectively, to determine the phenolic profiles by HPLC (HewlettPackard 1100, Agilent Technologies, Santa Clara, CA), as previously described (Guimarães et al., 2013). Detection was carried out with a diode array detector (DAD) using $280 \mathrm{~nm}$ and $370 \mathrm{~nm}$ as the preferred wavelengths connected in line with a mass spectrometer (API 3200 Qtrap; Applied Biosystems, Darmstadt, Germany). The phenolic compounds were identified by comparison of their retention times, UV-Vis and mass spectra with those obtained from standard compounds, if existing. Otherwise, peaks were tentatively identified by comparing the obtained information with previous studies performed in our laboratory (Dias, Barros, Fernandes, et al., 2015; Dias, Barros, Oliveira, et al., 2015; Dias, Barros, et al., 2016) and data in the literature (Del Bubba et al., 2012; Gasperotti et al., 2013; Simirgiotis \& Schmeda-Hirschmann, 2010; Sun, Liu, Yang, Slovin, \& Chen, 2014; Yildirim \& Turker, 2014). For quantitative analysis, individual standards calibration curves were constructed based on the area of the peaks recorded at $280 \mathrm{~nm}$ or $370 \mathrm{~nm}$. For the identified phenolic compounds with no available commercial standard, the quantification was performed based on the calibration curve of a similar compound belonging to the same phenolic group. The results were expressed in $\mathrm{mg}$ per $\mathrm{g}$ of plant material.

\subsubsection{Antioxidant activity}

The lyophilized extracts, infusions and decoctions were redissolved in methanol:water $(80: 20, v / v)$ and water, respectively, to obtain stock solutions of $0.625 \mathrm{mg} / \mathrm{mL}$, which were further diluted to obtain a range of six concentrations below the stock solution for antioxidant activity evaluation.

DPPH radical-scavenging activity was evaluated by using an ELX800 microplate reader (Bio-Tek Instruments, Inc., Winooski, VT), mixing $270 \mu \mathrm{L}$ of DPPH solution $\left(6 \times 10^{5} \mathrm{~mol} / \mathrm{L}\right)$ with $30 \mu \mathrm{L}$ of sample concentrations; mixtures were left for one hour in the dark at room temperature. The percentage of DPPH discoloration was calculated using the formula: $\left[\left(A_{\mathrm{DPPH}}-A_{\mathrm{S}}\right) / A_{\mathrm{DPPH}}\right] \times 100$, where $A_{\mathrm{S}}$ is the absorbance of the solution containing the sample at $515 \mathrm{~nm}$, and $A_{\mathrm{DPPH}}$ is the absorbance of the DPPH solution (Barros, Heleno, Carvalho, \& Ferreira, 2009; Barros et al., 2013).

Reducing power was evaluated by the capacity to convert $\mathrm{Fe}^{3+}$ into $\mathrm{Fe}^{2+}$ by mixing an aliquot of the extract solutions $(0.5 \mathrm{~mL})$ with $0.5 \mathrm{~mL}$ of sodium phosphate buffer $(200 \mathrm{mmol} / \mathrm{L}, \mathrm{pH} 6.6)$ and $0.5 \mathrm{~mL}$ of potassium ferricyanide $(1 \% \mathrm{w} / \mathrm{v})$ and incubating at $50{ }^{\circ} \mathrm{C}$ for $20 \mathrm{~min}$. The mixture $(0.8 \mathrm{~mL})$ was then placed in 48 -well microplates containing $0.8 \mathrm{~mL}$ of deionised water and $0.16 \mathrm{~mL}$ of ferric chloride $(0.1 \% w / v)$, measuring the absorbance at $690 \mathrm{~nm}$ in the microplate reader mentioned above (Barros et al., 2009; Barros et al., 2013). Inhibition of $\beta$-carotene bleaching was evaluated through the $\beta$-carotene/linoleate assay; briefly a $0.2 \mathrm{mg} / \mathrm{mL}$ solution of $\beta$-carotene was prepared to which was added linoleic acid $(40 \mathrm{mg})$, Tween $80(400 \mathrm{mg})$ and distilled water $(100 \mathrm{~mL})$ in a flask, followed by vigorous shaking. Different concentrations of the extracts $(0.2 \mathrm{~mL})$ were added to test tubes and mixed with aliquots of the previously prepared emulsion $(4.8 \mathrm{~mL})$ and zero time absorbance was measured at $470 \mathrm{~nm}$. The test tubes were put in a water bath at $50{ }^{\circ} \mathrm{C}$ for $2 \mathrm{~h}$, after which the absorbance was measured. The neutralization of linoleate free radicals prevents $\beta$-carotene bleaching, which is measured by the formula:

( $\beta$ - carotene absorbance after $2 \mathrm{~h}$ of assay/initial absorbance) $\times 100$

(Barros et al., 2009; Barros et al., 2013).

Lipid peroxidation inhibition in porcine brain homogenates was evaluated by the decrease in thiobarbituric acid reactive substances (TBARS). Firstly, a pig brain tissue (Sus crofa) homogenate was prepared with ice-cold Tris- $\mathrm{HCl}$ buffer $(20 \mathrm{mM}, \mathrm{pH}$ 7.4). The obtained supernatant was incubated with extract solutions $(0.2 \mathrm{~mL}), \mathrm{FeSO}_{4}(10 \mu \mathrm{M} ; 0.1 \mathrm{ml})$ and ascorbic acid $(0.1 \mathrm{mM}$; $0.1 \mathrm{~mL}$ ) at $37^{\circ} \mathrm{C}$ for $1 \mathrm{~h}$. The reaction was then stopped with trichloroacetic acid $(28 \% w / v, 0.5 \mathrm{~mL})$, followed by thiobarbituric acid (TBA, $2 \% w / v, 0.38 \mathrm{~mL}$ ), and the mixture was then heated at $80^{\circ} \mathrm{C}$ for $20 \mathrm{~min}$. The colour intensity of the malondialdehyde- 
thiobarbituric acid (MDA-TBA) was measured by its absorbance at $532 \mathrm{~nm}$; the inhibition ratio (\%) was calculated using the formula: $[(A-B) / A] \times 100 \%$,where $A$ and $B$ were the absorbances of the control and the sample solution, respectively (Barros et al., 2013; Barros, Heleno, Carvalho, and Ferreira, 2009). The final results were expressed as $\mathrm{EC}_{50}$ values $(\mu \mathrm{g} / \mathrm{mL})$, sample concentration providing $50 \%$ of antioxidant activity or 0.5 of absorbance in the reducing power assay. Trolox was used as positive control.

\subsection{Statistical analysis}

All the extractions were performed in triplicate and all the assays were also carried out in triplicate. The results are expressed as mean values and standard deviation (SD). The results were analyzed using Student's $t$-test, in order to determine the significant difference between two different samples, with $\alpha=0.05$. This treatment was carried out using SPSS v. 22.0 program.

\section{Results and discussion}

\subsection{Nutritional and chemical characterization of the lyophilized plant material and aqueous consumption forms}

Data on the nutritional and chemical composition of the in vitro cultured vegetative parts of $F$. vesca are shown in Table 1. Carbohydrates (including fiber) were the most abundant macronutrient $(84 \mathrm{~g} / 100 \mathrm{~g} \mathrm{dw})$, followed by proteins, ash and fat $(7,6.5$ and $2 \mathrm{~g} / 100 \mathrm{~g}$ dw, respectively). Compared to wild grown vegetative parts of $F$. vesca (Dias, Barros, Morales et al., 2015), the in vitro sam-

Table 1

Nutritional value, fatty acids, soluble sugars, organic acids and tocopherols content of in vitro cultured vegetative parts from wild Fragaria vesca L. (mean \pm SD).

\begin{tabular}{|c|c|c|c|}
\hline Nutritional value & $(\mathrm{g} / 100 \mathrm{~g} \mathrm{dw})$ & Soluble sugars & $\mathrm{g} / 100 \mathrm{~g} \mathrm{dw}$ \\
\hline Fat & $2.37 \pm 0.01$ & Xylose & $0.98 \pm 0.02$ \\
\hline Proteins & $7.27 \pm 0.12$ & Fructose & $2.55 \pm 0.17$ \\
\hline Ash & $6.53 \pm 0.20$ & Glucose & $3.94 \pm 0.17$ \\
\hline Total carbohydrates & $83.83 \pm 0.06$ & Sucrose & $2.20 \pm 0.01$ \\
\hline \multirow{2}{*}{$\begin{array}{l}\text { Energy } \\
\qquad(\text { kcal/100 g dw })\end{array}$} & $385.73 \pm 0.57$ & Trehalose & $0.35 \pm 0.06$ \\
\hline & & Sum & $10.04 \pm 0.26$ \\
\hline Fatty acids & (relative percentage) & Organic acids & $\mathrm{g} / 100 \mathrm{~g} \mathrm{dw}$ \\
\hline $\mathrm{C} 6: 0$ & $0.16 \pm 0.01$ & Oxalic acid & $3.76 \pm 0.06$ \\
\hline $\mathrm{C} 8: 0$ & $0.34 \pm 0.01$ & Quinic acid & $0.85 \pm 0.05$ \\
\hline C10:0 & $0.22 \pm 0.02$ & Shikimic acid & $0.002 \pm 0.001$ \\
\hline $\mathrm{C} 12: 0$ & $2.65 \pm 0.12$ & Ascorbic acid & $0.02 \pm 0.01$ \\
\hline $\mathrm{C} 14: 1$ & $3.03 \pm 0.07$ & Succinic acid & $1.58 \pm 0.20$ \\
\hline C15:1 & $0.61 \pm 0.04$ & Fumaric acid & $\operatorname{tr}$ \\
\hline C16:0 & $21.37 \pm 0.17$ & Sum & $6.20 \pm 0.21$ \\
\hline C16:1 & $0.56 \pm 0.09$ & & \\
\hline C17:0 & $0.57 \pm 0.004$ & & \\
\hline C18:1n9 & $5.62 \pm 0.08$ & & \\
\hline $\mathrm{C} 18: 2 \mathrm{n} 6$ & $16.11 \pm 0.05$ & & \\
\hline$C 18: 3 n 6$ & $37.54 \pm 0.46$ & Tocopherols & $\mathrm{mg} / 100 \mathrm{~g} \mathrm{dw}$ \\
\hline C20:1 & $6.85 \pm 0.05$ & $\alpha$-Tocopherol & $98.54 \pm 0.90$ \\
\hline $\mathrm{C} 22: \ln 9$ & $4.38 \pm 0.01$ & $\beta$-Tocopherol & $4.90 \pm 0.04$ \\
\hline SFA & $25.01 \pm 0.15$ & $\gamma$-Tocopherol & $24.86 \pm 0.23$ \\
\hline MUFA & $21.34 \pm 0.56$ & $\delta$-Tocopherol & $11.04 \pm 0.10$ \\
\hline PUFA & $53.56 \pm 0.41$ & Sum & $139.35 \pm 1.27$ \\
\hline
\end{tabular}

nd- not detected; tr- traces. SFA- saturated fatty acids, MUFA- monounsaturated fatty acids, PUFA- polyunsaturated fatty acids. Calibration curves for organic acids: oxalic acid $\left(y=9 \times 106 x+377946, R^{2}=0.994\right)$; quinic acid $(y=6010607 x+46061$, $\left.R^{2}=0.9995\right)$; shikimic acid $\left(y=7 \times 107 x+175156, R^{2}=0.9999\right)$; ascorbic acid $\left(y=108 x+751815, R^{2}=0.998\right)$; succinic acid $\left(y=603298 x+4994.1, R^{2}=1\right)$ and fumaric acid ( $\left.y=154862 x+1 \times 106, R^{2}=0.9977\right)$. (<LOD: 12.6, 24, 6, 3, 19 and 0.080 $\mu \mathrm{g} / \mathrm{mL}$ for oxalic, quinic, shikimic, ascorbic, succinic and fumaric acid respectively); (<LOQ: 42, 81, 19, 11, 64 and $0.26 \mu \mathrm{g} / \mathrm{mL}$ for oxalic, quinic, shikimic, ascorbic, succinic and fumaric acid respectively). ple had higher content of protein and lower content of ash, whereas the values of fat and carbohydrates were similar.

Fourteen different fatty acids were found, more than half being polyunsaturated fatty acids (PUFA), mainly linoleic acid (C18:2n-6, $16 \%)$ and $\gamma$-linolenic acid (C18:3n-6, 38\%). Palmitic acid (C16:0) was also found at high levels (22\%). Dias, Barros, Morales et al. (2015) reported lower percentages of total polyunsaturated fatty acids (41\%) and higher levels of saturated fatty acids (53\%) in wild-grown vegetative parts of $F$. vesca. These results are motivating, since PUFA are components of membrane phospholipids, serve as precursors of some hormones with vital roles in the human body and are also important in the protection against some diseases, such as rheumatoid arthritis, psoriasis and some age-related diseases, such as Alzheimer's (Patil \& Gislerød, 2006).

The profile of soluble sugars in the lyophilized plant material (Table 1 ) and in the aqueous preparations (Table 2) was very similar, glucose being the most abundant in all samples $(4 \mathrm{~g} / 100 \mathrm{~g} \mathrm{dw}$ in the dry sample, $9 \mathrm{mg} / 100 \mathrm{~mL}$ in the infusion and $10 \mathrm{mg} / \mathrm{mL}$ in the decoction). Fructose was the second major sugar found in the lyophilized plant material and in the decoction $(3 \mathrm{~g} / 100 \mathrm{dw}$ and $7 \mathrm{mg} / 100 \mathrm{~mL}$, respectively), while for the infusion sucrose (6 mg/100 mL) appeared as the second major sugar. Compared with the results obtained by Dias, Barros, Morales, et al. (2015), the in vitro sample showed higher content of soluble sugars than the wild grown vegetative parts (total sugars $=6 \mathrm{~g} / 100 \mathrm{~g} \mathrm{dw}$ ); furthermore, xylose was not previously described in the dry sample of $F$. vesca. These findings might indicate that the plant is producing larger amounts of sugars to maintain its vital functions of growth and development, since it is limited by the in vitro culture itself. In vitro plants have an incipient photosynthesis, and for that a higher amount of sugars in the medium is required, but some plants, under in vitro conditions, have a photosynthetic apparatus more developed than others, and if so, they can produce and store more sugars, like glucose, mannose, xylose or even raffinose; the type of sugar depends on the type of transportation in phloem, and that depends on the genetic characteristics of the plant species (Yaseen, Ahmad, Sablok, Standardi, \& Hafiz, 2013).

Table 2

Soluble sugars, organic acids and tocopherols contents in infusions and decoctions prepared from in vitro cultured vegetative parts of wild Fragaria vesca L. (mean \pm SD).

\begin{tabular}{llll}
\hline Soluble sugars & $\begin{array}{l}\text { Infusions } \\
\mathrm{mg} / 100 \mathrm{~mL}\end{array}$ & $\begin{array}{l}\text { Decoctions } \\
\mathrm{mg} / 100 \mathrm{~mL}\end{array}$ & $t$-Student p-value \\
\hline Xylose & $2.85 \pm 0.07$ & $2.89 \pm 0.20$ & 0.572 \\
Fructose & $6.12 \pm 0.15$ & $7.15 \pm 0.39$ & $<0.001$ \\
Glucose & $9.49 \pm 0.05$ & $10.14 \pm 0.80$ & 0.013 \\
Sucrose & $6.48 \pm 0.27$ & $3.29 \pm 0.20$ & $<0.001$ \\
Trehalose & $1.17 \pm 0.14$ & $0.66 \pm 0.14$ & $<0.001$ \\
Sum & $26.13 \pm 0.23$ & $24.13 \pm 1.46$ & $<0.001$ \\
Organic acids & $\mathrm{mg} / 100 \mathrm{~mL}$ & $\mathrm{mg} / 100 \mathrm{~mL}$ & \\
\hline Oxalic acid & $6.44 \pm 0.01$ & $5.55 \pm 0.01$ & $<0.001$ \\
Quinic acid & $4.958 \pm 0.003$ & $5.572 \pm 0.001$ & $<0.001$ \\
Shikimic acid & $0.086 \pm 0.001$ & $0.117 \pm 0.001$ & $<0.001$ \\
Fumaric acid & $\operatorname{tr}$ & $\operatorname{tr}$ & - \\
Sum & $11.48 \pm 0.26$ & $11.24 \pm 0.24$ & $<0.001$ \\
Tocopherols & $\mu \mathrm{g} / 100 \mathrm{~mL}$ & $\mu \mathrm{g} / 100 \mathrm{~mL}$ & \\
\hline$\alpha$-Tocopherol & $0.16 \pm 0.02$ & $0.17 \pm 0.01$ & 0.310 \\
$\beta$-Tocopherol & $1.82 \pm 0.08$ & $1.49 \pm 0.01$ & $<0.001$ \\
Sum & $1.98 \pm 0.06$ & $1.66 \pm 0.01$ & $<0.001$ \\
\hline
\end{tabular}

tr- traces. Calibration curves for organic acids: oxalic acid $(y=9 \times 106 x+377946$, $\left.R^{2}=0.994\right)$; quinic acid $\left(y=6010607 x+46061, R^{2}=0.9995\right) ;$ shikimic acid $\left(y=7 \times 107 x+175156, R^{2}=0.9999\right)$; ascorbic acid $\left(y=108 x+751815, R^{2}=0.998\right)$; succinic acid $\left(y=603298 x+4994.1, R^{2}=1\right)$ and fumaric acid $(y=154862 x$ $\left.+1 \times 106, R^{2}=0.9977\right) .(<$ LOD: $12.6,24,6$ and $0.080 \mu \mathrm{g} / \mathrm{mL}$ for oxalic, quinic, shikimic and fumaric acid respectively); (<LOQ: 42, 81, 19 and $0.26 \mu \mathrm{g} / \mathrm{mL}$ for oxalic, quinic, shikimic and fumaric acid respectively). 
Regarding organic acids, oxalic acid was the major one found in the lyophilized plant material $(3.76 \mathrm{~g} / 100 \mathrm{~g} \mathrm{dw})$ followed by succinic acid ( $1.58 \mathrm{~g} / 100 \mathrm{~g} \mathrm{dw})$; other acids, and among them ascorbic acid, were found at very low levels. Oxalic acid was also the predominant acid found in the infusions, although in that case followed by quinic acid ( 6 and $5 \mathrm{mg} / 100 \mathrm{~mL}$, respectively), and quite similar amounts of these two organic acids were found in decoctions. As for sugars and fatty acids, the organic acids content in the in vitro cultured samples was significantly higher than the one reported by Dias, Barros, Morales, et al. (2015) in wild-grown vegetative parts and corresponding infusions $(5.48 \mathrm{~g} / 100 \mathrm{~g} \mathrm{dw}$, $9.99 \mathrm{mg} / 100 \mathrm{~mL}$, respectively).

The four tocopherol isoforms were found in the lyophilized plant material, with $\alpha$-tocopherol as predominant ( $99 \mathrm{mg} / 100 \mathrm{~g} \mathrm{dw}$ ) followed by $\gamma$-tocopherol ( $25 \mathrm{mg} / 100 \mathrm{~g} \mathrm{dw})$. However, only $\alpha$ - and $\beta$ tocopherol were detected in the infusions and decoctions, the latter being the major one in both preparations, as can be seen in Fig. 1 . The lower content of tocopherols in the aqueous preparations was expected, due to their lipophilic character. Quite interestingly, the lyophilized plant material, infusions and decoctions of the in vitro cultured samples herein studied showed much higher tocopherol levels (139 mg/100 dw, 1.98 and $1.66 \mu \mathrm{g} / 100 \mathrm{~mL}$, respectively) than the equivalent ones obtained from wild-grown vegetative parts of $F$. vesca ( $7 \mathrm{mg} / 100 \mathrm{~g} \mathrm{dw}, 0.19$ and $0.22 \mu \mathrm{g} / 100 \mathrm{~mL}$, respectively), in which only one isoform ( $\alpha$-tocopherol) was reported in the infusions and decoctions (Dias, Barros, Morales, et al., 2015).

\subsection{Phenolic profile and antioxidant activity of the hydromethanolic extracts and aqueous preparations}

Table 3 presents the peak characteristics (retention time, wavelength of maximum absorption and mass spectral data), tentative identification and quantification of the phenolic compounds present in the hydromethanolic extracts, infusions and decoctions of the in vitro cultured vegetative parts of $F$. vesca. An example phenolic profile of the hydromethanolic extract recorded at 280 and $370 \mathrm{~nm}$ is shown in Fig. 2. Thirty different phenolic compounds where identified in the samples, four phenolic acids (peaks 8,11 , 12 and 14), twelve ellagic acid derivatives (peaks $1,3,9,10,15$, 17, 18, 24, 25, 28, 29 and 30), four flavan-3-ols (peaks 2, 4, 6, and 7), nine flavonols (peaks 5,13, 16, 19, 20, 21, 23, 26 and 27) and one dihydroflavonol (peak 22). The hydromethanolic extracts and the aqueous preparations showed a very similar profile, only distinguished at the quantification level and by the absence of some compounds in infusions and decoctions.

Most of the detected compounds (i.e., peaks 1-6, 8-10, 13, 15, 17-30) have been previously described in wild $F$. vesca and other Fragaria species (Del Bubba et al., 2012; Dias et al., 2016; Dias, Barros, Fernandes, et al., 2015; Dias, Barros, Oliveira, et al., 2015; Gasperotti et al., 2013; Simirgiotis \& Schmeda-Hirschmann, 2010; Sun et al., 2014), so that their identities are assumed herein. To the author's best knowledge, peaks 7, 11, 12, 14 and 16 have not been reported before in $F$. vesca. Although no information could be obtained regarding mass characteristics of peak 7 , it was tentatively associated to a flavan-3-ol, based on the characteristic shape of its UV spectrum; the observed $\lambda_{\max }$ at $272 \mathrm{~nm}$ would point to a gallocatechin or a derived proanthocyanidin (e.g., a prodelphinidin), expected to have maximum wavelength at lower values than catechins and related procyanidins (278-280 nm). Peaks 11 and 12 were tentatively identified as coumaroylquinic acid isomers according to their pseudomolecular ion $[\mathrm{M}-\mathrm{H}]-$ at $m / z$ 337, releasing fragments at $\mathrm{m} / z 191$ and $\mathrm{m} / \mathrm{z} 163$ corresponding to the deprotonated quinic acid and the coumaric acid moiety, respectively. Peak 14 was identified as feruloylquinic acid based on its pseudomolecular ion $[\mathrm{M}-\mathrm{H}]-\mathrm{m} / z$ at 367 and the production of a major daughter ion at $m / z 193$ [ferulic acid - H]-. Peak 16 showed a UV spectrum with $\lambda_{\max }$ at $368 \mathrm{~nm}$, a pseudomolecular ion [M $\left.-\mathrm{H}\right]-$ at $m / z 477$ and MS $^{2}$ fragments at $m / z 315$ and 301, which allowed its tentative identification as isorhamnetin-O-glucoside.

The methanolic extract presented higher concentrations of total phenolic compounds $(44 \mathrm{mg} / \mathrm{g}$ ) than the aqueous preparations (26-31 mg/g), mainly due to its greater content of ellagic acid derivatives $(19 \mathrm{mg} / \mathrm{g}$ ). Peak 17 (sanguiin H10 isomer) was the major compound found in the methanolic extracts, followed by

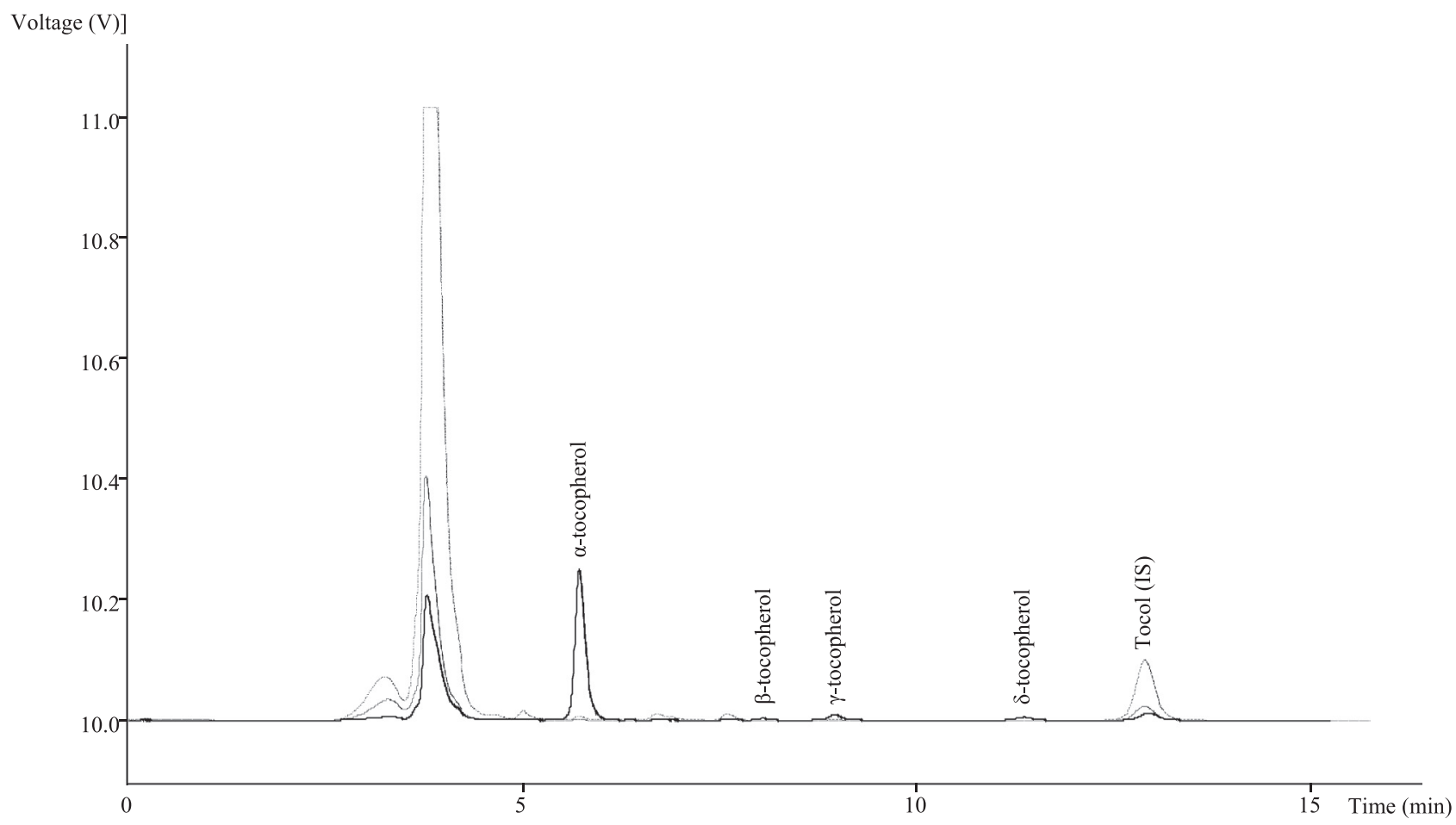

Fig. 1. Tocopherol profile of the hydromethanolic extract (--), infusion (-----) and decoctions (-.--.-.) preparations of in vitro grown plants of Fragaria vesca L. 
Table 3

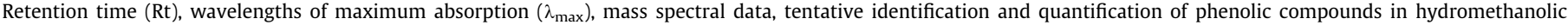
extracts, infusions and decoctions of the in vitro cultured vegetative parts of wild Fragaria vesca $\mathrm{L}$.

\begin{tabular}{|c|c|c|c|c|c|c|c|c|}
\hline \multirow[t]{2}{*}{ Peak } & \multirow[t]{2}{*}{$\begin{array}{l}\text { Rt } \\
(\min )\end{array}$} & \multirow[t]{2}{*}{$\begin{array}{l}\lambda_{\max } \\
(\mathrm{nm})\end{array}$} & \multirow[t]{2}{*}{$\begin{array}{l}{[\mathrm{M}-\mathrm{H}]^{-}} \\
(m / z)\end{array}$} & \multirow[t]{2}{*}{$\mathrm{MS}^{2}(m / z)$} & \multirow[t]{2}{*}{ Tentative identification } & Extracts & Infusions & Decoctions \\
\hline & & & & & & \multicolumn{3}{|c|}{ Phenolic compounds (mg/g dw) } \\
\hline 1 & 4.7 & 258 & 783 & $481(3), 301(30)$ & Bis-HHDP-hexoside ${ }^{B}$ & $0.027 \pm 0.001^{\mathrm{a}}$ & $0.027 \pm 0.001^{\mathrm{c}}$ & $0.028 \pm 0.003^{b}$ \\
\hline 2 & 5.6 & 278 & 451 & $289(100)$ & (Epi)catechin hexoside ${ }^{\mathrm{A}}$ & $0.060 \pm 0.001^{\mathrm{b}}$ & $0.081 \pm 0.004^{c}$ & $0.173 \pm 0.001^{\mathrm{a}}$ \\
\hline 3 & 6.05 & 256 & 783 & $481(25), 301(14)$ & Bis-HHDP-hexoside ${ }^{\mathrm{B}}$ & $0.006 \pm 0.002^{\mathrm{c}}$ & $0.015 \pm 0.03^{\mathrm{b}}$ & $0.033 \pm 0.002^{\mathrm{a}}$ \\
\hline 4 & 6.87 & 278 & 577 & $\begin{array}{l}\text { 451(33), 425(65), 407(100), } \\
289(75), 287(17)\end{array}$ & Procyanidin dimer ${ }^{A}$ & $0.09 \pm 0.01^{\mathrm{a}}$ & $0.071 \pm 0.002^{\mathrm{b}}$ & $0.07 \pm 0.01^{\mathrm{b}}$ \\
\hline 5 & 7.19 & 356 & 639 & $463(69), 301(59)$ & Quercetin glucuronyl-hexoside $\mathrm{E}^{\mathrm{E}}$ & $0.001 \pm 0.0001^{\mathrm{c}}$ & $0.003 \pm 0.001^{\mathrm{b}}$ & $0.004 \pm 0.001^{\mathrm{a}}$ \\
\hline 6 & 7.76 & 278 & 289 & 245(35), 203(32), 137(32) & $(+)$-Catechin ${ }^{\mathrm{A}}$ & $0.051 \pm 0.002^{\mathrm{c}}$ & $0.102 \pm 0.001^{\mathrm{b}}$ & $0.117 \pm 0.004^{\mathrm{a}}$ \\
\hline 7 & 8.35 & 272 & - & $425(65), 407(), 289(100)$ & Gallocatechin-related flavan-3-ol ${ }^{\mathrm{A}}$ & $0.039 \pm 0.001^{\mathrm{a}}$ & $0.033 \pm 0.001^{c}$ & $0.051 \pm 0.001^{\mathrm{b}}$ \\
\hline 8 & 9.63 & 332 & 355 & $193(18), 175(100), 161(20)$ & Ferulic acid hexoside $\mathrm{C}^{\mathrm{C}}$ & $0.006 \pm 0.001^{\mathrm{a}}$ & $0.005 \pm 0.001^{\mathrm{c}}$ & $0.006 \pm 0.001^{\mathrm{b}}$ \\
\hline 9 & 14.5 & 270 & 935 & $633(25), 301(21)$ & Galloyl-bis-HHDP-glucose isomer ${ }^{B}$ & $0.031 \pm 0.001$ & nd & nd \\
\hline 10 & 15 & 372 & 463 & $301(100)$ & Ellagic acid hexoside ${ }^{B}$ & $0.006 \pm 0.001^{\mathrm{a}}$ & $0.007 \pm 0.001^{\mathrm{b}}$ & $0.005 \pm 0.001^{\mathrm{c}}$ \\
\hline 11 & 15.45 & 316 & 337 & $\begin{array}{l}\text { 191(7),173(35),163(10),155 } \\
(5)\end{array}$ & Coumaroylquinic acid isomer ${ }^{\mathrm{F}}$ & $0.008 \pm 0.001 \mathrm{a}$ & $0.010 \pm 0.001^{\mathrm{b}}$ & $0.010 \pm 0.001^{\mathrm{b}}$ \\
\hline 12 & 15.7 & 316 & 337 & $\begin{array}{l}191(8), 173(38), 163(12), 155 \\
(6)\end{array}$ & Coumaroylquinic acid isomer ${ }^{\mathrm{F}}$ & $0.003 \pm 0.001^{\mathrm{b}}$ & $0.009 \pm 0.002^{\mathrm{a}}$ & $0.005 \pm 0.001^{b}$ \\
\hline 13 & 16.61 & 352 & 623 & $301(100)$ & Quercetin rhamnosyl-glucuronide ${ }^{\mathrm{E}}$ & $0.003 \pm 0.001^{\mathrm{b}}$ & $0.004 \pm 0.001^{\mathrm{b}}$ & $0.005 \pm 0.001^{\mathrm{a}}$ \\
\hline 14 & 16.75 & 320 & 367 & $\begin{array}{l}193(100), 191(16), 173 \\
(14), 149(25)\end{array}$ & Feruloylquinic acid ${ }^{\mathrm{C}}$ & $0.003 \pm 0.001^{\mathrm{c}}$ & $0.008 \pm 0.001^{\mathrm{b}}$ & $0.007 \pm 0.001^{\mathrm{a}}$ \\
\hline 15 & 17.07 & 372 & 433 & $301(100)$ & Ellagic acid pentoside $\mathrm{B}^{\mathrm{B}}$ & $0.004 \pm 0.001$ & $\operatorname{tr}$ & nd \\
\hline 16 & 17.59 & 368 & 477 & $315(35), 301(100)$ & Isorhamnetin-O-glucoside ${ }^{\mathrm{D}}$ & $0.016 \pm 0.001^{\mathrm{a}}$ & $0.021 \pm 0.001^{\mathrm{b}}$ & $0.017 \pm 0.001^{\mathrm{c}}$ \\
\hline 17 & 17.93 & 262 & 1567 & $\begin{array}{l}935(95), 783(5), 631(2), 613 \\
(13), 301(6)\end{array}$ & Sanguiin $h 10$ isomer $^{B}$ & $0.146 \pm 0.002$ & nd & nd \\
\hline 18 & 19.29 & $250 / \operatorname{sh} 370$ & 447 & $301(100)$ & Ellagic acid rhamnoside ${ }^{B}$ & $0.004 \pm 0.001^{\mathrm{b}}$ & $0.011 \pm 0.001^{\mathrm{a}}$ & $0.006 \pm 0.001^{\mathrm{b}}$ \\
\hline 19 & 19.3 & 346 & 607 & $285(100)$ & Kaempferol rhamnosyl-glucuronide $\mathrm{e}^{\mathrm{H}}$ & $0.01 \pm 0.001^{\mathrm{b}}$ & $0.015 \pm 0.001^{\mathrm{b}}$ & $0.019 \pm 0.001^{\mathrm{a}}$ \\
\hline 20 & 19.87 & 356 & 477 & $301(100)$ & Quercetin glucuronide ${ }^{\mathrm{E}}$ & $0.007 \pm 0.001^{\mathrm{a}}$ & $0.010 \pm 0.001^{\mathrm{c}}$ & $0.010 \pm 0.001^{b}$ \\
\hline 21 & 20.04 & 354 & 637 & $315(95), 300(26)$ & Methylquercetin rhamnosyl glucuronide $\mathrm{E}^{\mathrm{E}}$ & $0.003 \pm 0.001^{\mathrm{c}}$ & $0.005 \pm 0.001^{\mathrm{b}}$ & $0.006 \pm 0.001^{\mathrm{a}}$ \\
\hline 22 & 20.18 & $292 / \operatorname{sh} 338$ & 435 & $303(100)$ & Taxifolin-pentoside $\mathrm{G}^{\mathrm{G}}$ & $0.039 \pm 0.001^{\mathrm{a}}$ & $0.048 \pm 0.002^{\mathrm{b}}$ & $0.035 \pm 0.004^{c}$ \\
\hline 23 & 20.56 & 356 & 463 & $301(100)$ & Quercetin 3-O-glucoside ${ }^{\mathrm{E}}$ & $0.003 \pm 0.001$ & nd & nd \\
\hline 24 & 21.11 & $254 / \operatorname{sh} 370$ & 301 & $284(4), 256(3), 229(4), 185(4)$ & Ellagic acid $^{\mathrm{B}}$ & $0.012 \pm 0.001^{\mathrm{b}}$ & $0.037 \pm 0.001^{\mathrm{a}}$ & $\operatorname{tr}$ \\
\hline 25 & 23.35 & 378 & 447 & $315(28), 300(100)$ & Methyl ellagic acid pentoside $\mathrm{B}^{\mathrm{B}}$ & $\operatorname{tr}$ & $\operatorname{tr}$ & $0.034 \pm 0.002$ \\
\hline 26 & 23.9 & 348 & 461 & $285(100)$ & Kaempferol-glucuronide ${ }^{\mathrm{H}}$ & $0.004 \pm 0.001^{\mathrm{a}}$ & $0.006 \pm 0.001^{\mathrm{b}}$ & $0.006 \pm 0.001^{\mathrm{a}}$ \\
\hline 27 & 24.21 & 348 & 447 & $285(100)$ & Kaempferol-hexoside $\mathrm{H}^{\mathrm{H}}$ & $0.002 \pm 0.001^{\mathrm{a}}$ & $0.002 \pm 0.001^{\mathrm{c}}$ & $0.002 \pm 0.001^{\mathrm{b}}$ \\
\hline 28 & 24.83 & 364 & 447 & $315(12), 300(100)$ & Methyl ellagic acid pentoside ${ }^{B}$ & $\operatorname{tr}$ & $\operatorname{tr}$ & $\operatorname{tr}$ \\
\hline 29 & 25.26 & $248 / \operatorname{sh} 372$ & 461 & $315(89), 301(38)$ & Dimethyl ellagic acid pentoside ${ }^{B}$ & $0.024 \pm 0.001^{\mathrm{a}}$ & $0.021 \pm 0.001^{\mathrm{b}}$ & $0.011 \pm 0.001^{\mathrm{c}}$ \\
\hline \multirow[t]{6}{*}{30} & 26.98 & 368 & 461 & $315(37), 301(100)$ & Dymethyl ellagic acid pentoside ${ }^{B}$ & $\operatorname{tr}$ & $\operatorname{tr}$ & $\operatorname{tr}$ \\
\hline & & & & & Total phenolic acids & $0.019 \pm 0.001^{\mathrm{b}}$ & $0.032 \pm 0.001^{\mathrm{a}}$ & $0.027 \pm 0.001^{\mathrm{c}}$ \\
\hline & & & & & Total ellagic acid derivatives & $0.26 \pm 0.01^{\mathrm{a}}$ & $0.119 \pm 0.001^{\mathrm{b}}$ & $0.118 \pm 0.001^{\mathrm{b}}$ \\
\hline & & & & & Total flavan 3-ols & $0.089 \pm 0.001^{\mathrm{a}}$ & $0.113 \pm 0.002^{\mathrm{b}}$ & $0.104 \pm 0.006^{c}$ \\
\hline & & & & & Total flavonols & $0.235 \pm 0.003^{b}$ & $0.287 \pm 0.002^{c}$ & $0.409 \pm 0.003^{a}$ \\
\hline & & & & & Total phenolic compounds & $0.6 \pm 0.01^{\mathrm{a}}$ & $0.551 \pm 0.003^{c}$ & $0.658 \pm 0.001^{b}$ \\
\hline
\end{tabular}

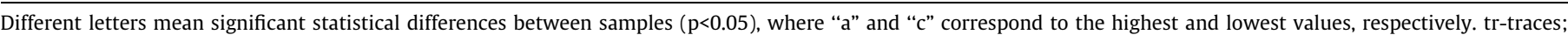

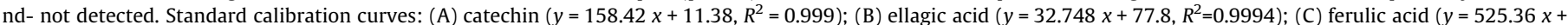

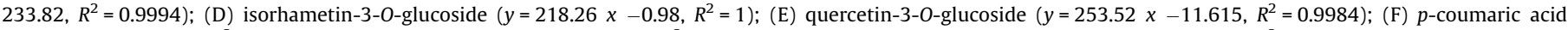
$\left(y=706.09 x+1228.1, R^{2}=0.9989\right) ;(G)$ taxifolin $\left(y=224.31 x+148.41, R^{2}=0.999\right) ;(\mathrm{H})$ kaempferol-3-O-glucoside $\left(y=288.55 x-4.0503, R^{2}=1\right)$.

peak 4 (procyanidin dimer). Different observations regarding the phenolic profile of in vitro-grown leaves of $F$. vesca were made by Yildirim and Turker (2014), who only reported two compounds in common with those detected in our study (i.e., (+)-catechin and a procyanidin dimer), and in much lower amounts.

Smaller contents of phenolic compounds were determined in the present study than previously found in wild grown vegetative parts (Dias, Barros, Fernandes, et al., 2015a). A possible explanation might be the short stationary phase in the growth of the in vitro-cultured plants, which would lead to lower yields in the production of secondary metabolites, due to the inhibition of the action of enzymes normally present in mature plants (Dias et al., 2016). Furthermore, in vitro-grown plants are not as subjected to environmental stress as wild plants, a factor that is known to influence phenolic accumulation. All in all, this could mean that in vitro-grown $F$. vesca would need to be elicited to produce higher amounts of phenolics.

\subsection{Antioxidant activity of the hydromethanolic extracts and aqueous preparations}

The results on the antioxidant activity of the hydromethanolic extract, infusions and decoctions of in vitro cultured vegetative parts are collected in Table 4. The hydromethanolic extract showed the highest DPPH-scavenging activity and reducing power $\left(\mathrm{EC}_{50}=83\right.$ and $57 \mu \mathrm{g} / \mathrm{mL}$, respectively), while for $\beta$-carotene bleaching inhibition and TBARS inhibition the lowest $\mathrm{EC}_{50}$ values were observed for the infusions $\left(\mathrm{EC}_{50}=52\right.$ and $25 \mu \mathrm{g} / \mathrm{mL}$, respectively). The results found for reducing power can be moderately correlated with the contents of phenolic acid derivatives in the samples $\left(r^{2}=0.777\right)$, while for TBARS inhibition the results were highly correlated with these compounds $\left(r^{2}=0.903\right)$, especially with ellagic acid derivatives $\left(r^{2}=0.9908\right)$, as well as with flavonols $\left(r^{2}=0.915\right)$.

The antioxidant activities found for the hydromethanolic extract in the DDPH scavenging, reducing power and $\beta$-carotene assays were higher than those observed for the extracts of wild grown vegetative parts of $F$. vesca L., despite the latter contained higher concentrations of phenolic compounds $(138 \mathrm{mg} / \mathrm{g}$ ) (Dias, Barros, Fernandes, et al., 2015). This could be due to the different phenolic profiles existing in both types of samples, but also to the presence of other components in the extracts, such as sugars, organic acids or tocopherols, which occur in higher levels in the in vitro-cultured sample, and may also have an influence on the antioxidant potential. 
$\mathbf{A}$

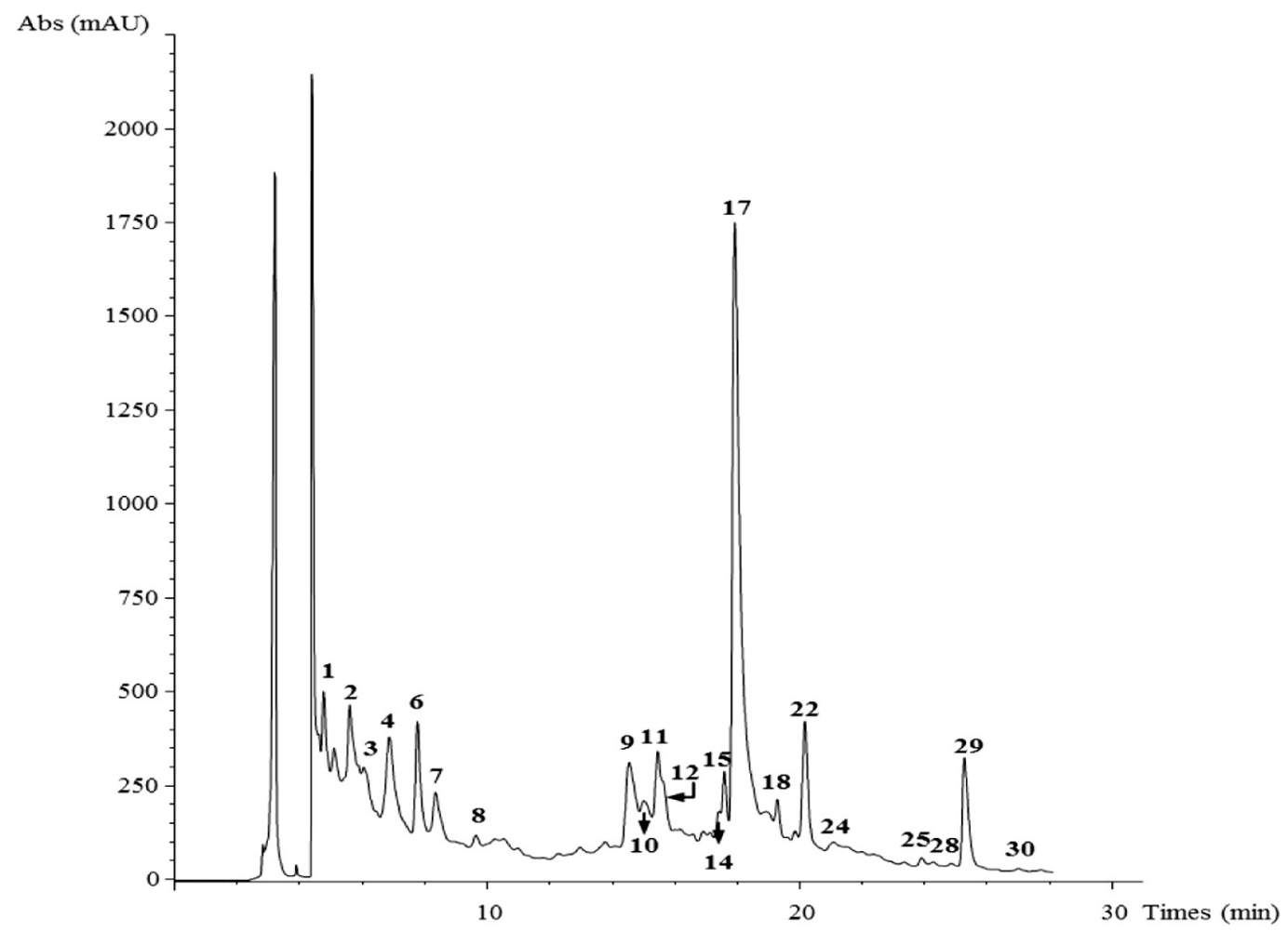

B

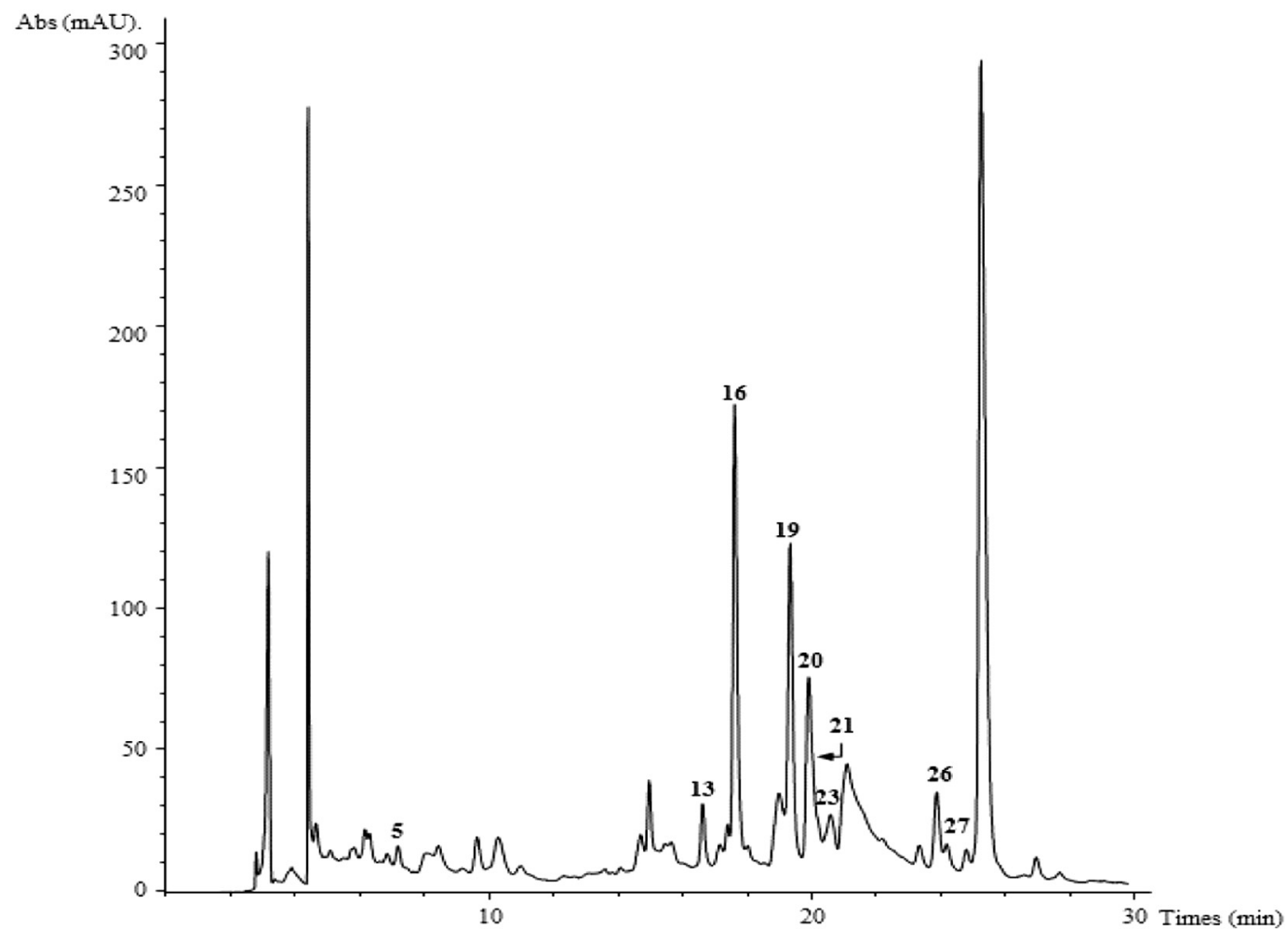

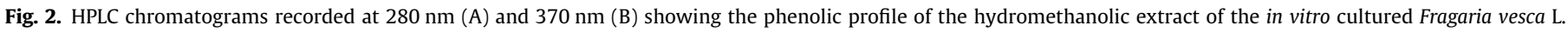

Overall, the plant tissue culture technique applied to Fragaria vesca $\mathrm{L}$. proved to be a suitable approach to obtain higher contents of proteins, polyunsaturated fatty acids, soluble sugars, organic acids (including ascorbic acid) and tocopherols (mainly $\alpha$-tocopherol). Furthermore, the hydromethanolic extracts of the in vitro-grown samples showed greater antioxidant activity than 
Table 4

Antioxidant activity of the hydromethanolic extracts, infusions and decoctions of in vitro cultured vegetative parts of wild Fragaria vesca $\mathrm{L}$.

\begin{tabular}{llll}
\hline $\mathrm{EC}_{50}$ values $(\mu \mathrm{g} / \mathrm{mL})$ & Hydromethanolic & Infusion & Decoction \\
\hline DPPH scavenging activity & $82.5 \pm 3.1^{\mathrm{b}}$ & $86.9 \pm 0.9^{\mathrm{ab}}$ & $93.6 \pm 10.1^{\mathrm{a}}$ \\
Reducing power & $57.0 \pm 0.1^{\mathrm{c}}$ & $75.9 \pm 0.4^{\mathrm{a}}$ & $62.0 \pm 0.3^{\mathrm{b}}$ \\
$\begin{array}{l}\beta \text {-carotene bleaching } \\
\quad \text { inhibition }\end{array}$ & $54.4 \pm 1.9^{\mathrm{a}}$ & $52.4 \pm 1.0^{\mathrm{b}}$ & $54.2 \pm 0.1^{\mathrm{a}}$ \\
& & & \\
TBARS inhibition & $230.3 \pm 16.1^{\mathrm{a}}$ & $25.3 \pm 0.8^{\mathrm{b}}$ & $27.1 \pm 1.6^{\mathrm{b}}$ \\
\hline
\end{tabular}

$\mathrm{EC}_{50}$ values correspond to the sample concentration achieving $50 \%$ of antioxidan activity or 0.5 of absorbance in reducing power assay. Trolox $\mathrm{EC}_{50}$ values: $43.03 \pm 1.71 \mu \mathrm{g} / \mathrm{mL}$ (DDPH), $29.62 \pm 3.15 \mu \mathrm{g} / \mathrm{mL}$ (reducing power), $2.63 \pm 0.14 \mu \mathrm{g} /$ $\mathrm{mL}$ ( $\beta$-carotene bleaching inhibition) and $3.73 \pm 1.9 \mu \mathrm{g} / \mathrm{mL}$ (TBARS inhibition). Different letters mean significant statistical differences between samples $(\mathrm{p}<0.05)$ where "a" and "c" correspond to the highest and lowest values, respectively.

the ones obtained from wild-grown $F$. vesca. In contrast, although the phenolic profile was similar to that observed in wild-grown plants, lower levels of total phenolic compounds were accumulated in the in vitro-cultured samples. Further studies are required to check if this limitation might be overcome by elicitation of plant growth.

\section{Acknowledgements}

The authors are grateful to Fundação para a Ciência e a Tecnologia (FCT, Portugal) for financial support to CIMO (strategic project UID/AGR/00690/2013) and to REQUIMTE (national funds and co-financed by FEDER, under the Partnership Agreement PT2020) and to POCI-01-0145-FEDER-006984 (LA LSRE-LCM) funded by ERDF through POCI-COMPETE2020 and FCT. L. Barros and M.I. Dias thank FCT for their grants (SFRH/BPD/107855/2015 and SFRH/BD/84485/2012, respectively). The GIP-USAL is financially supported by the Spanish Government through the project AGL2015-64522-C2-2-R.

\section{References}

Anand, S. (2010). Various approaches for secondary metabolite production through plant tissue culture. Pharmacia.

AOAC (2005). Official methods of analysis of AOAC international. In G. L. W. Horwitz (Ed.) (18th ed. (18th ed.). Gaithersburg: AOAC International.

Barros, L., Heleno, S. A., Carvalho, A. M., \& Ferreira, I. C. F. R. (2009). Systematic evaluation of the antioxidant potential of different parts of Foeniculum vulgare Mill. from Portugal. Food and Chemical Toxicology, 47, 2458-2464.

Barros, L., Pereira, E., Calhelha, R. C., Dueñas, M., Carvalho, A. M., Santos-Buelga, C., \& Ferreira, I. C. F. R. (2013). Bioactivity and chemical characterization in hydrophilic and lipophilic compounds of Chenopodium ambrosioides L. Journa of Functional Foods, 5(4), 1732-1740. http://dx.doi.org/10.1016/j. jff.2013.07.019.

Camejo-Rodrigues, J., Ascensão, L., Bonet, M. À., \& Vallès, J. (2003). An ethnobotanical study of medicinal and aromatic plants in the Natural Park of "Serra de São Mamede" (Portugal). Journal of Ethnopharmacology, 89(2-3) 199-209. http://dx.doi.org/10.1016/S0378-8741(03)00270-8.

Castroviejo, S., Aedo, C., Cirujano, S., Laínz, M., Montserrat, P., Morales, R., ... Soriano C. (1998). Flora Ibérica 6. In Real Jardín Botánico (Ed.). Madrid: CSIC.

Del Bubba, M., Checchini, L., Chiuminatto, U., Doumett, S., Fibbi, D., \& Giordani, E. (2012). Liquid chromatographic/electrospray ionization tandem mass spectrometric study of polyphenolic composition of four cultivars of Fragaria vesca $\mathrm{L}$. berries and their comparative evaluation. Journal of Mass Spectrometry, 47(9), 1207-1220. http://dx.doi.org/10.1002/jms.3030.

Dias, M. I., Barros, L., Fernandes, I. P., Ruphuy, G., Oliveira, M. B. P., Santos-Buelga, C., ... Ferreira, I. C. F. R. (2015). A bioactive formulation based on Fragaria vesca L. vegetative parts: Chemical characterisation and application in $\kappa$-carrageenan gelatin. Journal of Functional Foods, 16, 243-255. http://dx.doi.org/10.1016/j. jff.2015.04.044.
Dias, M. I., Barros, L., Morales, P., Cámara, M., Alves, M.-J., Oliveira, M. B. P., ... Ferreira, I. C. F. R. (2016). Wild Fragaria vesca L. fruits: a rich source of bioactive phytochemicals. Food \& Function, 4523-4532. http://dx.doi.org/10.1039/ c6fo01042c.

Dias, M. I., Barros, L., Morales, P., Sánchez-Mata, M. C., Oliveira, M. B. P. P. \& Ferreira, I. C. F. (2015). Nutritional parameters of infusions and decoctions obtained from Fragaria vesca L. roots and vegetative parts. LWT - Food Science and Technology, 62(1), 32-38. http://dx.doi.org/10.1016/j.lwt.2015.01.034.

Dias, M. I., Barros, L., Oliveira, M. B. P. P., Santos-Buelga, C., \& Ferreira, I. C. F. R. (2015). Phenolic profile and antioxidant properties of commercial and wild Fragaria vesca L. roots: A comparison between hydromethanolic and aqueous extracts. Industrial Crops and Products, 63, 125-132. http://dx.doi.org/10.1016/j. indcrop.2014.10.021.

Dias, M., Sousa, M., Alves, R., \& Ferreira, I. F. R. (2016). Exploring plant tissue culture to improve the production of phenolic compounds: A review. Industrial Crops and Products, 82, 9-22. http://dx.doi.org/10.1016/j.indcrop.2015.12.016.

Doumett, S., Fibbi, D., Cincinelli, A., Giordani, E., Nin, S., \& Del, M. (2011). Comparison of nutritional and nutraceutical properties in cultivated fruits of Fragaria vesca L. produced in Italy. FRIN, 44(5), 1209-1216. http://dx.doi.org/ 10.1016/j.foodres.2010.10.044.

Gasperotti, M., Masuero, D., Guella, G., Palmieri, L., Martinatti, P., Pojer, E., ... Vrhovsek, U. (2013). Evolution of ellagitannin content and profile during fruit ripening in Fragaria spp. Journal of Agricultural and Food Chemistry, 61(36), 8597-8607. http://dx.doi.org/10.1021/jf402706h.

Godfray, H., Beddington, J., Crute, I., Haddad, L., Lawrence, D., Muir, J., ... Toulmin, C. (2012). Food security the challenge of feeding 9 billion people. Science, 327, 812. http://dx.doi.org/10.4337/9780857939388.

Guimarães, R., Barros, L., Dueñas, M., Carvalho, A. M., Queiroz, M. J. R. P., SantosBuelga, C., \& Ferreira, I. C. F. R. (2013). Characterisation of phenolic compounds in wild fruits from Northeastern Portugal. Food Chemistry, 141(4), 3721-3730. http://dx.doi.org/10.1016/j.foodchem.2013.06.071.

Karuppusamy, S. (2009). A review on trends in production of secondary metabolites from higher plants by in vitro tissue, organ and cell cultures. Journal of Medicinal Plants Research, 3(13), 1222-1239. http://dx.doi.org/10.1117/12.644514.

Murashige, T., \& Skoog, F. (1962). A revised medium for rapid growth and bioassays with tobacco tissue cultures. Physiologia Plantarum, 15, 473-497.

Ornelas-Paz, J., Yahia, E. M., Ramírez-Bustamante, N., Pérez-Martínez, J. D., Escalante-Minakata, M., Ibarra-Junquera, V., ... Ochoa-Reyes, E. (2013). Physical attributes and chemical composition of organic strawberry fruit (Fragaria $\mathrm{x}$ ananassa Duch, Cv. Albion) at six stages of ripening. Food Chemistry, 138(1), 372-381. http://dx.doi.org/10.1016/j.foodchem.2012.11.006.

Özüdoru, B., Akaydin, G., Erik, S., \& Yesilada, E. (2011). Inferences from an ethnobotanical field expedition in the selected locations of Sivas and Yozgat provinces (Turkey). Journal of Ethnopharmacology, 137(1), 85-98. http://dx.doi. org/10.1016/j.jep.2011.04.050

Patil, V., \& Gislerød, H. R. (2006). The importance of omega-3 fatty acids in diet. Current Science, 90(7), 908-909.

Pawlaczyk, I., Czerchawski, L., Pilecki, W., Lamer-Zarawska, E., \& Gancarz, R. (2009). Polyphenolic-polysaccharide compounds from selected medicinal plants of Asteraceae and Rosaceae families: Chemical characterization and blood anticoagulant activity. Carbohydrate Polymers, 77(3), 568-575. http://dx.doi. $\operatorname{org} / 10.1016 /$ j.carbpol.2009.01.030

Regulation (EC) No 1169/2011 (2011). Regulation (EC) No 1169/2011 of the European Parliament and of the Council, of 25 October 2011, on the provision of food information to consumers. Official Journal of the European Union, 1169, $18-63$.

Savo, V., Giulia, C., Maria, G. P., \& David, R. (2011). Folk phytotherapy of the Amalfi Coast (Campania, Southern Italy). Journal of Ethnopharmacology, 135(2), 376-392. http://dx.doi.org/10.1016/j.jep.2011.03.027.

Simirgiotis, M. J., \& Schmeda-Hirschmann, G. (2010). Determination of phenolic composition and antioxidant activity in fruits, rhizomes and leaves of the white strawberry (Fragaria chiloensis spp. chiloensis form chiloensis) using HPLCDAD-ESI-MS and free radical quenching techniques. Journal of Food Composition and Analysis, 23(6), 545-553. http://dx.doi.org/10.1016/j.jfca.2009.08.020.

Sun, J., Liu, X., Yang, T., Slovin, J., \& Chen, P. (2014). Profiling polyphenols of two diploid strawberry (Fragaria vesca) inbred lines using UHPLC-HRMS n. Food Chemistry, 146, 289-298. http://dx.doi.org/10.1016/j.foodchem.2013.08.089.

Yaseen, M., Ahmad, T., Sablok, G., Standardi, A., \& Hafiz, I. A. (2013). Review: Role of carbon sources for in vitro plant growth and development. Molecular Biology Reports. http://dx.doi.org/10.1007/s11033-012-2299-z.

Yildirim, A. B., \& Turker, A. U. (2014). Effects of regeneration enhancers on micropropagation of $<\mathrm{i}>$ Fragaria vesca $<\mathrm{i} />\mathrm{L}$. and phenolic content comparison of field-grown and $<\mathrm{i}>$ in vitro<i/ $>$-grown plant materials by liquid chromatography-electrospray tandem mass spectrometry (LC-ESI-MS/MS). Scientia Horticulturae, 169, 169-178. http://dx.doi.org/10.1016/ j.scienta.2014.01.038. 